\title{
A Postcolonial Approach to Abduction in Indigenous Folksongs
}

\author{
Segun Omosule \\ Associate Professor \\ Department of English, Olabisi Onabanjo University, Nigeria \\ omosulesegun@gmail.com
}

DOI: 10.21608/MISJ.2021.58153.1019

Received: 14-2-2021

Accepted: 1-4-2021

Published: 10-5-2021

\section{Abstract}

Folklore in Africa harbours ample records of the forceful migration of folks from the continent to the new world. Two prominent Ifá verses record this untoward development. What may not be in the public domain, however, is the record of the scars, and the amount of tears, wailing and pains that the dislocation might have caused folks on account of their estrangement from their loved ones. Record of the moment and pains of forceful severance from siblings, parents and ancestral roots may have been captured in two oral records subsisting in relevant axioms and tales of the unforgettable onslaught. The first arising from the moment of despair was that the pain of a dead child would be easier to bear and forgotten than the anxiety surrounding the whereabouts of a missing child and the disappearance of two sisters in one fell swoop leaving traces of an unfinished piece of fried yam and another uneaten yam on fire that they were preparing for breakfast prelude to the onslaught as well as the soul searing songs they rendered while being captured by two different marauders. Using a combination of postcolonialism and semiotic, the paper sets out to unravel the pains and despair of estrangement and complement same with the history of slave trade, concluding that man's inhumanity to man has been a recurring decimal in the record of time.

Mistiqiya

International Journal of African-Egyptian Studies

Vol. 1 Issue 2 (2021) 
Key words: Abduction, Folklore, Orality, Post-colonialism, Translation, Semiotic

\section{Introduction}

Relics of the forceful migration of black people dot every part of the world. These may manifest in the population of black folks in the Diaspora as well as the seaports that facilitated the inhuman transactions. What may not be visible are the scars left on the folks through the marauding activities of the period. The scars may be imbued but the agonies, finding expression in the folksongs that only the sages could explain and provide necessary link with tears streaming down their cheeks over missing siblings, capture the helplessness of the people. The songs in the paper have been handed down to the younger generation and are verbally rendered during memorable occasions. They also constitute the subject matters of some Ifá verses. According to Bascom (1969), "Ifá is not associated with astrology, as Burton first observed, but rather with a series of memorised verses and stories upon which their interpretation depends" (Bascom, 1969). It is, in fact, the first language in the indigenous Yoruba environment. It incorporates metaphysics with some carefully selected folktales to deconstruct the human situation, and find credible solutions to such problems through necessary sacrifice.

The solemn lyrics in the related folktales recorded in the Ifá corpus are pointers to the inhumanity arising from the sudden loss of beloved; not just one or two but four and at times a family may be abducted in one fell swoop. The captives may soon grapple with the reality of their abduction but the bereaved are left to bear the pangs of separation and might have no option than to commit suicide or pass away through cardiac arrest resulting from the sudden reality of the loss of their precious ones. Domesticated goats may not be easily killed and any mishap to them may not be forgotten in a hurry. The losses are more than goats. They are human companions and the consequences may be total loss of hope, and ultimate afflictions, leading to fatal recourse.

One significant song reveals the psychological trauma of the era. Two If $a$ ' verses that capture the malaise of the period, namely 'Egitán 'Edi and Ohá Etúrá are recorded transcripts of historical developments and corroborate the banditry

\section{Mistiqiya}

International Journal of African-Egyptian Studies

Vol. 1 Issue 2 (2021) 
that ravaged the continent in the inhuman search for slaves. Wande Abimbola (1968, 1977, 1997), Ruth Finnegan (1968), William Bascom (1969), Ayo Bamgbose (1969), Ropo Sekoni (1994) are credible referents in the documentation of folktales in the indigenous African environments. Some of the tales exhibit the dejection and feeling of insecurity that pervaded the milieu for a long time. Tears may be said to have literally dropped like pebbles arising from the severance of loved ones from their parents; and relations from their communal folks with the attendant dejection, and jeers of everyone over the recollection of the unwarranted attacks on defenceless, simple and innocent agrarian people.

The serene African environment witnessed the onslaught on the innocent folks and one monarch who was particularly fingered as the arrowhead of the plague was Lárogb́o whose enclave was very close to the Ooweǹa River in the Benin axis of Western part of Nigeria. His exposure to the Europeans, who sold salt to folks, might be the singular reason for his marauding activities that greatly troubled the milieu; leaving on its trail orgies of blood and the emergence of a new lexical item in the milieu known as Kódokódo. An unspecified number of people must have been abducted by bandits that folks had to tag it as Lárogb̀o War.

No other nomenclature would have been more apt than the toga of war ascribed to it. The unprovoked war that saw everyone scampering for safety revealed the culpability of the black leadership too. Any wonder that many years after the activities, folks still have a reason to finger the unholy alliance of Lárogb̀o in the abduction of folks. Of course, Lárogbo had his domain at Akótógbo and had signed a trade pact with the Europeans prelude to the partition of the continent in 1883/4. His notoriety was unmatched by anyone in the area. Other slave intermediaries existed in the regions especially Ondo folks who prospected for slaves too and would abduct epidemic ravaged kids who must have been too fragile to seek cover in the face of the danger from ablebodied men and women they met while on lonely paths.

The endeavour in the paper involves historical, folkloric and social reactions to the unhindered abductions of folks from the African continent.

\section{Mistiqiya}

International Journal of African-Egyptian Studies

Vol. 1 Issue 2 (2021) 
These are contained in the axioms and folksongs subsisting in the oral environments. The research is a product of a fieldwork among the agrarian people of Ikále in Ondó State area of Nigeria. An excursion into the troubles of the era was provided with a simple rhetorical question: is it not more ennobling to know that one's child is dead than to be told that the child is missing? It is paradoxical but it should have been the other way round. A missing child may still be found through dogged efforts but a dead child may not have the hope of returning alive. That was, however, contrary to the experiences of the folks in the milieu during the era of unhindered abductions. The hope that the child might be lurking somewhere was enough to afflict the soul. The announcement of the death would be followed by a period of mourning and the submission that the giver (providence) must have taken him back.

It is equally psychological and beyond the moralisation that the imperialists might provide. The scars of the inhumanity would take eternity to heal just as the pains are unforgettable. The submission about the missing child is contained in the axiom subsisting in the environment: Oma né kú han ju Ọma ne hoǹu lo (transliterated to mean that the death of one's child is preferable to the news that he is missing). Of course, the trauma associated with the development may make one go nut. It is tantamount to an injury that may not be ever healed. The literary significance arises from the commitment of the folks to record their encounters with people, who though different in nature and worldviews, saw the black people as objects of demonstration of their bestiality and went beyond inhumanity to the plausibility or otherwise of regarding the invaders as human.

\section{Synopsis of the Folksong}

A particular folksong that evolved during the marauding activities of bandits was entitled: Bansa. The mixture of Hausa lexical item bansa meaning "madness" which might have been deployed in the folksong reveals the apparent madness resulting from the agonies of folks whose loved ones were stolen without any clue of their whereabouts till today. The choice of the word Bansa may have been informed by more than a mere desire to borrow from the neighbouring Hausa environment. Rather, the prevailing atmosphere of unprovoked attack and abductions of loved ones could have brought about the

\section{Nisriqiya}

International Journal of African-Egyptian Studies

Vol. 1 Issue 2 (2021) 
conclusion that existence was a mere madness after all. It could also have been informed by the desire to achieve rhythmic harmony arising from the creative dexterity of the composer. As a matter of fact, creativity may not be limited to the manipulation of ingredients from the indigenous environment alone as focus may be shifted to the contiguous environment for parallels to sum up the feelings of the folks at the moment of the agony as well as the search for an apt representation at the time of composition.

This short but precise folksong consists of a few lines and two stanzas. They sum up the underlying pains and invisible scars that the folks collectively harboured resulting from the aggression and inhumanity of man to man.

Bansa o, ye o ye o, bansa

Bansa o, oye ye, bansa

Bansa o, ye o ye o, bansa

ojó a ti gbo one mo ma

Mo deyin noyin ode, o ye, ye, bansa,

Bansa o.

Bansa o, ye o ye o, bansa

Bansa o, one mo ma yi, bansa

Bansa o, ye o ye o, bansa

Ikú o méja kák̀o,

É sài m̀oẁe eja, o dára bansa.

\section{Mistiqiya}




\section{Translation}

O madness, plain madness

Madness, sheer madness

Madness, plain madness

The day someone I used to know was abducted

I ceased from going out, o madness

O madness, plain madness

Madness, this victim I used to know

Plain madness

Madness, plain madness

It is death that overpowers fish not for lack of swimming prowess

It is too much, plain madness

Oh madness

Central to the conflict in the song is movement. The terrain was haunted and any stray beyond the vicinity of local stalwarts who kept vigil at the communities could spell doom for anyone. It is a wise decision not to steer outside in view of the insecurity there from. The persona in the tale exhibits that frustration immediately her relation is abducted. She abstains from venturing outside the confines of her home.

Other relevant semiotic objects are to be considered in this paper. The physical buildings dotting the coasts of Africa where slaves were kept prior to their shipment to the Americas and Europe are potent semiotic objects that provide concrete images of the veracity of the tales. In the Cape Coast are monuments of such relics such as Carolusburg or Slave Castles. Others are Elmina Castle, and Badagry Slave House, in Lagos. Other semiotic objects Misriqiya International Journal of African-Egyptian Studies

Vol. 1 Issue 2 (2021) 
under consideration are the cannons that litter the backyards of folks at Ode Irele, Igbobini, Ugbotu to mention but a few. They betray the era of abductions. History may be exaggerated and physical buildings may be destroyed but the cannons of warfare that sent cold jitters into the spines of local folks, when boomed with the attendant danger, may not be easily destroyed. The sinister sound sent everyone scampering for safety in different directions. That was the leeway that the raiders needed to make the folks vulnerable to attack and abduction and a possible inroad into the milieu.

These semiotic objects are the subject of analysis. They may be deployed to provide meanings to the objects beyond the limits of rational postulation. This is the strength in semiotic translation. The quest for meaning may not be limited to rational perusal or what the structuralists would call textual analysis. Meaning may go beyond the text. It may be situated within history. It may even be tied to the environment and the quarrel between Hippolyte Taine (1965) and Flaubert Gustave (1965) comes to the fore here. Every theory takes care of a single aspect of meaning in the text. Formalist's preoccupation with the way the words cohere in the text too may not be more than an effort in the way a particular word contributes to meaning. Structuralism is synonymous with intertextuality and undertakes the search for meaning from one text to another without particular attention to the full analytic realization of the meaning in any single text to the fullest. This is a palpable weakness in the theory.

Machlis (1955) provides the strength of the recourse to postmodernism which ultimate quest is the postcolonial discussion that the paper seeks to accomplish. It is the recognition of the place of the environment where a folk item originates from in the reconstruction and interpretation of the text. This is based on the fact that meaning is tied to the "secret world out of which it sprang. The greater our understanding, the more complete our possession of the art-work; and the better we capture the joy, the illumination that went into its making." Of course, the text devoid of the ennobling milieu may be nothing save a fish of its water. It is better imagined what manner of discomfort it would suffer. The psychological state of the folks at the moment of composition of the songs cannot but be brought to bear in any analysis of the song. Within that realization too is the place of the history of the people (Hyppolyte Taine, 1965).

\section{Mistiqiya}

International Journal of African-Egyptian Studies

Vol. 1 Issue 2 (2021) 
Post-colonialism is a resurrection from the demise of postmodernism and provides a theoretical base for the renegotiation and accommodation of realities from the peripheral: the peripheral here refers to "the other" and voiceless people of the world. It does not pretend to be all-encompassing. It only seeks a voice from the deafening pride of Eurocentric proclamation of absolutism. It negates the canons while accepting that the cannons of defeat in war and the ideology behind it all were mere fabrications and ideological constructs. As tools of silencing the folks, the cannons with the associated fire and the canons and their master narratives achieved their objectives of abduction, defeat, and silence. With the balm of peace poured on the raging heads of the oppressors, the inarticulate remnants of the dehumanized "other" find a mouthpiece in postcolonialism through a negation of power arrogation and consequent reverberation of their erstwhile shacked mouths and feet.

\section{Definition of Terms}

Folksongs refer to unconscious compositions of members of a culture arising from the record of debilitating challenges, moments of happiness and despair, witness of an unforgettable development and reposition of major landmarks that could only be stored in songs which may be recalled during the annual festive season. Folksongs may equally chronicle the challenges confronting a people at a time which made them sing from their unconscious expression of satisfaction and celebration of the development. Such songs refer to the collective scripts that are spontaneously composed based on their moments of happiness and dejection that the lyrics are hardly forgettable and may have assumed lyrical permanence. One significant aspect of folksongs is the fact that they belong to the community and no one could take credit for them.

The performance of folksongs may not be tied to a particular lead-singer. Every member of the community may sing depending on their desire to partake in the performance or not. The performance may be associated with other ensembles and musical instruments may be beaten. Among which is shekere. Shekere is an instrument that is made of beads around a calabash. Other wooden instruments may be brought to bear, particularly pátáka. It is made of wood and are usually two. Laz Ekwueme (2002) lends an authorial voice in the examination of folk music. According to him, folk performance is "antiphonal, Misriqiya International Journal of African-Egyptian Studies

Vol. 1 Issue 2 (2021) 
with a leader or ripieno announcing an antecedent to which a (larger) chorus responds." Members of the environment may support the rendition in order to achieve the best of the performance. This is in tandem with the wise saying in the milieu that it is the business of everyone to support the individual in order to prevent a miscarriage. This is opposed to the individuality that is prevalent in the western world.

Folklore, as cited in Moses, Oke, (2007) is a term coined by William John Thoms in (1846). It is an amalgam of "folk" and "lore". The root word "folk" refers to an infinitesimal group in its original sense. It is a means of identifying rural people who might not be associated with technology. The suffix "lore" is a reference to the artistic preoccupation of the people whose means of livelihood is tied to the agrarian sector. They are usually referred to as "rustic" people. The lore of the people is unwritten. "Wagner (1965) situates the origin of the term "folk" and observes that folk is limited in reference at the outset. According to him, "folk" has a limited scope and might be limited to the units usually the family and that the meaning might have assumed a wider dimension to include the society, the nation and of course humanity.

Folklore is verbal and it exists in the memories of the people. The truth is that a greater chunk of the arts of the people has been collected and may be found in print. Finnegan Ruth (1992) considers folklore to be "both an expressive and a socially significant aspect of human action, a form in which human beings use and develop artistically-marked conventions to formulate and manipulate, and actively create their own human existence and the world around them" (1992). Okpewho Isidore (1992) identifies the attributes of folklore and situates these with oral delivery. Ben-Amos (1975) identifies certain features of folklore items such as diffusion and multiple existence from which qualitative and structural changes could not be divorced as they cross geographical boundaries.

Utley (1965) is a treatise on folklore. He views folklore as a subject that is associated with the folks whose art is orally transmitted especially "found among primitive isolates or civilized marginal cultures, urban or rural societies, dominated or subordinate group." Alan Dundes (1965) considers folks to be "any group of people whatsoever who share at least one common factor. It does not matter what the linking factor is. It could be a common occupation, Misriqiya International Journal of African-Egyptian Studies

Vol. 1 Issue 2 (2021) 
language, or religion-but what is important is that a group formed for whatever reason will have some traditions which it calls its own" and the art is capable of diffusion.

Prelude to the efforts of researchers to document the lore of the people, the folks are the custodians of the arts and such arts may only be attainable through performance at the arena in the presence of an audience. Members of the audience too are "active bearers" of the tradition and may be handy where the storyteller suffers from memory loss. The "active bearers of tradition" according to Sydow (1948) are secular folks. This may not be true in relation to the performance of Ifá folktales. The "active bearers of tradition" here are religious. The same is applicable to the performers during Eje, Ere and Irokite festivals. At the ritual arena, the performers are involved in religious activities such as offering of prayers for the peaceful convocation of the festival and peace and prosperity of the people thereafter.

Far from folklore being seen as stagnant, it is subject to creativity depending on the ingenuity of the artists. This is what Dan Ben - Amos (1975) considers to be "creativity and esthetic response." Francis Vas da Silva (2020) negates the view of a dead-end associated with folklore: "...the popular view of tradition as a static, past state of things is arguably a fable" and would rather consider this to be dynamic. Dundes (1987) would rather see "symbolic equivalences" in folklore as the attempt at stigmatising tradition smacks of ignorance. Francis Vas da Silva (2020) associates folklore with "synthesis" or "accidental variation" which may be due to the creative dexterity of the artists. These views are different ways of looking at the artistic quests of folks.

\section{Ogunpolu's Adaptation of Propp's Taxonomy}

Ogunpolu (1990) adapts Propp's (1966) model while examining Yoruba folktales. Arewa O. and Shreve, G. M. (1975) are equally relevant in the adaptation of Propp that this paper considers apt in the discussion. Their analysis was based on tales from Zande tricksters and it attempted a theory of African folktales on the basis of structure especially from the perspectives of Alan Dundes and Levi-Strauss. Ogunpolu (1990) further identifies the allomotifs that are generalized in the motifeme. The present study re-enacts the primordial inhibitions and attempts an adaptation of Propp's model to the Mistiqiya International Journal of African-Egyptian Studies

Vol. 1 Issue 2 (2021) 
folktale in the paper by fashioning the following findings. According to Anozie, S. O. (1981), the trio of Vladimir Propp, Alan Dundes and Claude Levi-Strauss which represent the structuralists' approach to the study of folklore and "have to a considerable extent dominated and even displaced traditional post-war attitudes towards folkloristics..." The paper examines the structure in the story in the folksong using the models of Vladimir Propp, Alan Dundes and Claude Levi-Strauss.

Step 1: The folksong involves a lone walker on the countryside of the African continent. She ventures out of the view of her parents and she is abducted.

Step 2: There is no information about her whereabouts and the conclusion is that she has been abducted by slave merchants who haunted the environment during the era of slavery and slave trade.

Step 3: Her tale becomes a subject of folksong in the environment in order to sensitise the younger generation about the danger of traversing lonely paths where they might be abducted and sold into slavery.

Step 4: $\quad$ The singer expresses her circumspection in going out ever since the individual she is acquainted with becomes a victim of abduction. The lesson in the song is that the environment is not safe and that folks could be abducted at will without any trace or hope of eventual return.

\section{Adaptation of Propp / Ogunpolu's Method:}

\section{Abduction of a lone walker}

(a) Classification: Journey Motif

(b) Motifs: Quest, Exploration, Adventure, Travel, Sojourn, Relocation to another clime, Movement, Disappearance etc.

(c) Other folktales of abduction are latent in the environment and may reveal the agonies of bereavement such as More and Tete and Bejebejerodemi.

\section{Mistiqiya}




\section{The Incorporating the Folksong into the Ifa Corpus}

Meaning becomes a polemical issue in the treatment of cultures and the meanings they attribute to situations. This is what Henry Louis Gates (1989) calls the "signifyin $(\mathrm{g})$." The question of meaning may be subject to manipulation whereby what a particular word means to the majority may be different from the original meaning allotted to it in the original, originating setting. In this regards, the "signifyin(g)" may be tantamount to symbols or secret ideograms. Brad Bucknell (2020), while citing Gates (1989), considers this to be the "black cultural matrix." Gates (1989) "slave's trope of tropes" is "a theory of formal revision; it is tropological; it is often characterized by pastiche; and, most crucially, it turns on repetition of formal structures, and their difference." It is an attribute of indigenous Yoruba folktales to be subjected to formal analysis both within the physical realm and the metaphysical interpretation of present and future relationship of the clients within the society and in relation to other folks in the environment.

\section{Application of Vladimir Propp's Morphology of Folktales to the Folksong}

a. The parents of the persona are absent from home. The name of the persona is not stated and this may not be unrelated to the fear of insulting the parents.

b. The parents are wailing at home in view of the knowledge of the mishap that could happen to her in view of the marauding activities of kidnappers and slave prospectors.

c. The parents gave an interdiction to the children not to go out. The initial situation may be seen from the disobedience of the persona to the advice of the parents not to go out. She could have visited the contiguous village to celebrate a festival against the advice of the parents or on a mission to visit a male friend. From the perspective of Vladimir Propp (1966), an "interdiction" is an admonition to the kids not to go out or break any particular rule.

d. The persona breaks the rule by venturing beyond the boundary set by the parents.

\section{Nistiqiya}


e. There is a search for the venue of the festival and this amounts to what Propp (1966) considers to be "reconnaissance." The victim is on her way to the venue of the performance when she is apprehended by the abductors.

f. The victim's plea for mercy did not appeal to the senses of the abductors.

g. The victim submits and accepts the inevitability of her abduction. She becomes bold and more resolute to face the fact of her abduction. According to her, nightfall has met the lone walker during a long journey and must brace up with the reality of the moment and be emboldened.

\section{Theoretical Framework}

Tejumola Olaniyan (2015) provides the strong point for the adoption of postcolonial literature that forms the theoretical foundation of the paper. According to him, "the term postcolonialism precludes the colonial era of the people whose issues: history, policies and challenges are represented in the theory..." While the truth in the claim of Olaniyan may not be denied, postcolonialism does not obliterate the colonial era from the thesis of the discourse. McClintock (1992) as cited in Tejumola Olaniyan (2015) admits that the term postcolonialism encompasses the "colonial experience" and "the political and epistemological authority of Europe-as the master key to reading the diverse histories and cultures of erstwhile imperialised African societies."

Postcolonialism becomes a platform for the discussion of the challenges of the pre-and colonial era. The issues under discussion fall under the purview of the study and this makes postcolonialism a veritable theoretical tool for the analysis of the paper, as it provides the leeway for a return to the era and the narratives surrounding whatever worldviews, folksongs and perceptions that might have evolved from the debris of the relationship between the West and the supposed "other". Apart from situating the development within known history, the paper shall adopt postcolonialism, semiotics and the Vladimir Propp's taxonomy of folktales in reconstructing the relevant items that are instrumental in the analysis. The place of signs may not be over-emphasised in the study of indigenous songs. This is so as the basic signs may not be divorced from the communication processes. For instance, an outsider may misconstrue 
the songs as mere expressions of happiness rather than the communication of historically conjured development, deeply rooted pains and recollections of the gory details of abductions and severance of loved ones from their siblings at a period in the history of the people.

The adoption of postcolonial discourse may further complement the analytic tools of semiotic and interpretation of one or two casual statements from the emerging environment that are representative of the critical situation permeating the milieu. A basic script that corroborates this claim relates the stubborn disposition of one of the folks with untamed penchant for roaming the enclave against the superior admonition of the elders: E ke dun Lége ni, é la wok̀o oỳinbó (we are only expressing our concern for Lége; he can't escape the white man's ship). The white man's ship here is the slave ship that conveys folks against their will to the plantations abroad. The ship is dreaded as the unpredictable outcome of a visitation to its abode may be fatal. Consequently, semiotics provide the signs from which the study can extrapolate from the concrete facts with the desire to lay bare the deeply rooted meanings of the songs and axioms and possibly correlate these with the historical past which does not derail from the preoccupation of postcolonialism and "the acceptance of oral tradition in the construction of African history" (Tejumola Olaniyan, 2013).

\section{Application/Analysis}

The relevance of semiotics to the study becomes visible from the realisation that the songs may not be easily understood even by indigenes from the immediate environment which is referred to as the originating system. The song may amount to another contribution to the repertoire of songs in the environment if the meaning is understood by the present generation. The sonorous tune, notwithstanding, the song is latent with relevant messages that captured the hell that the slave traders unleashed on innocent members of the people. If it could not be understood by people from the originating sign system, it would be difficult to be appreciated by people from another sign system. It is in this regard that semiotic becomes a ready tool of analysis of the semiotic words in the song.

\section{Mistiqiya}

International Journal of African-Egyptian Studies

Vol. 1 Issue 2 (2021) 
Stecconi Ubaldo (2010) provides a working definition of semiotics thus: "semiotics can be described as the discipline that studies how people make sense of their experience of the world and how cultures develop and give currency to this understanding". The world in the extract may be limited to the environment of the sign system. The system harbours historical and cultural landmarks that are significant to them and any interpretation of these oral texts may be instrumental in the way they view and understand their past, and the present in relation to the future. The development, the world over, about the presence of black people in the new world and beyond may be further provided necessary illumination through semiotic interpretation of the song.

The slave trade port at Badagry, Lagos State, Nigeria becomes a visible semiotic object. The cannons (eturu in local parlance) that dot the backyards of most homes in the rural areas are similar semiotic objects. These have become cultural signs to the indigenous folks. A semiotic translation and interpretation of such objects may be all the folks need to re-live the past and thus arrive at a better understanding of the present. It is through the appreciation of the roles of translation and interpretation of some signs in the indigenous environments that the exploits of the raiders could be understood. It is consequently considered apt to deploy "semiotics" which is "ultimately a theory of how we produce, interpret and negotiate meaning through signs" as this becomes a valid tool of analysis (Stecconi, 2010).

A critique of the colonial experience may not be complete without a mention of the painful component of the colonial scars. The sore infested relics of that encounter leave sour taste of unending bitterness in contradistinction to the infantile celebration of the empire and the cloudy disengagement which marked the mine infested bestowal of independence by the imperial authority. Such relics of brutality, domination and estrangement are not without subtle, tacit and conscious reverberations. How much of such bruises can be measured depends on the victims and may be exacerbated by the policy of the dominating forces and the attitude or humanity/inhumanity of the commanders of the imperial army. The stigma that the imperial will stamped on the carefully composed, systematised means of divination such as the Ifá corpus which they smeared with the criminal emblem of "clever crook and crazy crank" in view of

\section{Mistiqiya}

International Journal of African-Egyptian Studies

Vol. 1 Issue 2 (2021) 
their inability to systematically study an elevated socio-religious culture that imposed a high level of morality, probity, honesty and self appraisal on the people betrays their ignorance.

The irony of a battered religiosity is the postmodern clamour for the scientific device that now becomes the toast of the millennium by the descendants of the erstwhile detractors; a metaphor of a backdoor quest for the rejected stone. It thus may be safety claimed that the IfálAfá (as our Igbo siblings would refer to the same religious/artistic tool latent in Ifá, (the indigenous Yorubá metaphysics) may hold the key to a pragmatic, futuristic analytical investment of a global dimension in a few decades and some lustrum to come. This is not farfetched. Rather, it is a pointer to the growing quest for practical solutions to nagging physical and spiritual problems. The focus may now be more important than the wholesale plunge into the unknown when a focal lens is available to direct the sleepwalker to a possible harbour.

Equally pathetic is the successful denigration of whatever was salient to the colonized as barbaric. That was the crust of modernism and blind submission about absolutism and the objectivity of culture. Of course, that was to be expected since the oppressors held the instruments of control and could exert these in favour of their goals. The imperativeness may be tied to the need to convince critics of the colonial enterprise that it was meant to redeem the folks from their trapped pigeonholes from which survival could not have been possible without the supposed mission of retrieval. Today, not more than one hundred million adherents of indigenous African religions may be found in Africa; but the exotic, politically imposed religions have assumed the status of state religions just as practitioners of indigenous religions assume a toga of illegality and must be licensed before they could practice. These are, no doubt, relics of colonial presence and may thus assume the stigma of post-colonial phenomenon of conscious approval of colonial insignia of subjugation, relegation and conquest in all ramifications.

The religious-minded scholars among us will be quick to identify savagery in our religions that tilts significantly towards barbarity. This may not constitute an exception, and consequent justification for the rejection and total

\section{Mistiqiya}

International Journal of African-Egyptian Studies

Vol. 1 Issue 2 (2021) 
submersion of our totality in the exotic religions. The history of both Christianity and Islam is rife with much mind boggling contradictions, such that the individual would query the sanctity, sanity and sweeping claim to spirituality. The mindless murders of innocent souls on trumped up charge of scriptural motivations are enough to throw one off balance and question the foundations of these exotic religions. The crux of the argument is that there is nothing barbaric in indigenous religions that is not equally salient to the two exotic religions laced with the murder of several million human beings in the guise of proselytising their creeds.

If such bestiality is given historical documentation, the colonial society would be undeniably an epitome of inhumanity and unbelievers may want to remain in a state of perpetual doubt. It becomes doubtful that the exponents of such magnitude of inhumanity were conscious of Shakespeare's much touted "milk of human kindness" (Macbeth, 2019) and the properties that should go with it. Alex Haley's Roots (1976) may be considered apt all through time when issues of slavery, slave trade, domination, brutality and dehumanising the other race are being considered. The botched attempt at justifying whatever may befall man as the will of God/Allah or whatever nomenclatures and attributes may be consciously stamped on the godhead are readily debunked as mere diplomatic escapades.

"All things are the will of Allah." The response of the Wolof shackle-mate sums it up: "If your Allah wills this, give me the devil."

That singular revelation from the Wolof mars the relationship between him and Kunta. It has not ceased to be in the modern times. The dawn of technology and other sundry components have opened the eyes to the inhumanity inherent in the affairs of the world powers in relation to "the other" where religions are the potent tools of domination.

The racial question is a conscious trajectory of imposition. The conquest by the first world begins with the amplification of greed. The limited level of their civilization may not be detached from the goal too. This is equally informed by innate desire for selfish expansion, manipulation, and the presentation of the mask of disquietude in the colonised. The mask finds expression in the tale of the trickster god in the Yorubá enclave and the two

\section{Misriqiya}

International Journal of African-Egyptian Studies

Vol. 1 Issue 2 (2021) 
siblings who had boasted that nothing could bring disagreement between them. The trickster god sewed a long cap, with each side having a different colour. He passed between the two siblings with the cap on and each side of the cap had a different colour. The ensuing argument brought to the fore the tendency to manipulate innocent ones through tacit diplomacy and conscious deployment of brutality.

The tool of social subtraction is no longer hidden from the probing eyes of critics. Andrew Milner (1994) claims, in reference to postmodernism, that the quest is far from the "politics of demystification through reactivation, its central achievement and aspiration, the discovery not of hidden truths, but of marginalized inconsistency was within dominant discourses (97). The study seeks to reconstruct the questions of "the centre", "the metropolis", "the periphery" and the issue of "the other" from the point of view of sentimentality, rupture of the family setting, displacement and displacement of one generation against another (Tejumola Olaniyan, 643).

The first successful arrow of cultural displacement was the overthrow of African myths. Myths and values were debunked and in their place, more puerile ones were established especially, through conscious manipulation of the younger generation. The colonial enterprise was to set kids against their parents. It did not end there. The choice of education was such that would set the kids against their parents. The ensuing animosity led to inter-generational furor that totally displaced the erstwhile cohesion witnessed in the milieu. It became fashionable, therefore, for the kids to denounce their parents and negate their warnings and instructions. The focus was always on non-existing things that could compare with the false luxury presented by the foreigners.

These African myths were replicated with their exact parallels in the invading culture. Saturn, Sun-god and all others took over the religion and mythical space and were hardly understood by the conquered folks who paraded minimal knowledge in deploying poetic knowledge of myths. Soyinka, I. Ogunbusola (2019) provides illuminating equivalents of these cosmic personalities that are venerated by indigenous folks prelude to colonialism: Ogun became Aries; Jove, Óshun became Venus; Orisha 'Ibeji became

\section{Mistiqiya}

International Journal of African-Egyptian Studies

Vol. 1 Issue 2 (2021) 
Mercury, Orúnìila became Leo, Oya became Pluto, Ọbatala became Jupiter, Obaluaye became Saturn, Sango the god of thunder became Uranus. If such parallels exist in the two different climes, it will amount to self glorification/Eurocentricism to consider one category superior to the other.

The colonial project had its halcyon weaknesses on the land and people. For example, the relation with the green environment was negated. Before then, it was a symbiotic relationship between the agrarian folks and other folks, on one hand, and folks and nature, on the other hand. What they took from nature was immediately returned in form of appreciation and ritual deployment symbolic of interactive communication with each other. Appeals and supplications were made to the land and nature generally. A mutual understanding subsists that the folks walk on the land without negating the taboos surrounding it and never despoiling it for any reason. It was based on the knowledge of the inherent life in the elements which probably informed the reasons the land was worshipped in order to induce it to yield its best and wherever such infraction might have been perceived, the remission would be quick and drastic involving the most ranking member to the least folk; paying homage to it and adding rituals of purification for immediate regeneration. It might not be too sweeping to associate indigenous people with the much touted Green Revolution finding expression in eco-criticism and the urge to replenish the land as much as possible.

The pre-colonial era was particularly fruitful through the manifest recognition of the subsisting myths. Such recognition conferred moral probity and collective acceptance of the immanence of the deities/taboos, and the negation of which attracted fatal consequences. The few members of the communities/religious environment adhered to these religiously. Although it might not be said to be perfect, as no society prides on the claim to cultural and absolute objectivity but cultural subjectivity, time would have smoothened such crooked paths through reforms as might be occasioned by the intellectual uplift of the sages.

Indigenous societies spell out rules. The peak that everyone must attain in order to live long, to be worthy of being considered an ancestor, being able to 
visit relations during the biennial celebration of Ogúngún-Pípe, when ancestors are assumed to visit the physical realm to relate with their loved ones and provide information on some nagging spiritual conflicts in the family, is defined. The goal remains inherent in everyone and any deviation may spell doom for the individual e.g. suicide, murder, stealing etc. The consciousness haunts the individual all through a lifetime and develops in the course of time. Examples abound of such self regulating socio-political policies such as selling without the owners, buying with fidelity, chastity and the honour of virginity before marriage etc.

The colonial enterprise was not without its strengths too. The religious embodiment of folk amounts to the backlash involving the emergence of daring individuals that failed to recognize the potency of such myths and taboos. While the indigenous folks believed in immediate retributive justice, the new found religions gave room for confession and hypothetical forgiveness of sins which gave man the latitude to commit more sins while relishing in the euphoria of forgiveness upon the confession.

Slavery became a new song. This is symbolic "of that pigmy legend of the little boy who finds the bird with the beautiful song in the forest and brings it home". "He asks his father to bring food for the bird and the father doesn't want to feed a mere bird; so he kills it. And the legend says the man killed the bird and with the bird, he killed the song and with himself, he dropped dead, completely dead and was dead forever" (Campbell, 2019). The re-interpretation of the onslaught may be construed from the point of view of a song. The suffocation of the bird nipped its song in the bud. The slaves and their marginalised remnants in Africa are the songs. The dehumanisation meted unto them with the attendant killing of the folks led to a corresponding visitation of death on the invaders. The physical and spiritual violence assume a new dimension; it amounts to committing hara-kiri. The spilled blood of the people is bound to germinate and repopulate the world. It is the message of the bird and its song.

A reading of Joseph Campbell's The Power of Myths (2019) provides a clue to the origin of animosity exhibited by members of the "in-group" 
represented by the colonial masters and their relics in relation to the "out-group" which is "the other". The authorial force being the Ten Commandments knocks and negates itself with the admonition that says "Go in to Canaan and kill everybody in it". It is apparent that the scriptures in the raw form would be anathema to peaceful co-existence; except with the intervention of the New Testament's admonition of turning the left cheeks if someone slaps the right cheek. It is a historical fact that Black Africans were humiliated and reduced to animalistic caricatures through piercing the lips, and with padlocks securely placed. The tradition is, no doubt, handed down from the Jewish tradition of piercing the ear of the slave (Exodus, 21: 1-6). The gory picture takes the same form in the Arab world and their relationship with other people, especially black folks.

\section{Semiotic Objects and Interpretation}

Three distinct signs are involved in any analysis of folksongs. Each depicts the situation of the people during the era. From the helpless to the acceptance and resignation of folks to the reality of their entanglement, the semiotic objects when translated and interpreted would paint a picture of the horrid situation haunting the atmosphere during the era under review. In the centre of the orgy was the outside world named Ode. This may be considered the semiotic object. It is visible and represents the outside world within the enclave and beyond the recesses of the milieu. The challenges involving the outside world are legion. It involves the missing reed; a synonym for the umbilical cord that ties the individuals with the foundation of their existence. It is also a symbol of severance from the hunter's whistle. When detachment is the lot of the individual, the folks believe, would hamper the voice and mar the sanctity of the voice. One becomes voiceless as if chanting the creed of love in the crowd of noisy wine drinkers. The voice loses its potency and becomes voiceless.

In the middle of the conflict is the individual who is known but that must remain nameless. No one dare mention the name because of the sorrow involved and the stigma associated with the name. He is simply someone I used to know but that must not be mentioned. He is represented by the word gbé (abducted).

\section{Mistiqiya}

International Journal of African-Egyptian Studies

Vol. 1 Issue 2 (2021) 
Of course, it would be unthinkable to mention names when the injuries of such abduction are yet to heal. Allusions may be made and the personalities may be known but names may only be mentioned in hushes and silence. The pains arising from such mysterious disappearance of folks were inexplicable and the phenomenon was tagged kódokódo, to depict the enigma of missing folks while on a journey.

Of course, bansa refers to the prevailing madness. It is the best description of the era. The consequence of mass abduction of loved ones cannot but be followed by insanity; not from any fault with the gene but the accumulated reaction to a harsh situation that could not be readily redressed. The tale of a woman was narrated. She was caught in the melee. Her only son was abducted and she lost her sanity instantly. She began to search for the missing son amid singing. The lyric of her song pointed to a strange development that was flying around in the sky. She then urged everyone not to look up but down. That was the only song she could sing all through her lifetime.

The song reveals the heavy burden that the folks had to bear over the mindless loss of their beloved to the activities of slave traders consisting of white and Arab merchants. The melee was not far removed from instant death sentence. It was arrogant display of brute force that time can hardly obliterate. That explains why the tone of death and dejection permeates the folksong. The metaphor of a dead fish captures the helplessness of the erstwhile powerful folks who were reduced to captives upon whose necks were hung chains and wood that rendered them helpless and from which they had no hope of escape in the face of assailants whose visitations they did not prepare for.

Equally pointing at the insecurity of the era was another statement that exhorts the individual to be wary of his uncoordinated movement in the woods. His stubborn demeanour, however, would serve as a stumbling block to every plea to stay within visible arena. As a result of his indiscretion, the folks concluded that his case was irredeemable; which led to the emergence of the statement concluding him to be a potential scapegoat who might be destined for the white man's ship: E ke dun Lége ni, é la wok̀o oỳinbó. Lége was an individual. He may constitute the semiotic object. Every trait of him proves that

\section{Mistiqiya}

International Journal of African-Egyptian Studies

Vol. 1 Issue 2 (2021) 
he would be captured as he loiters in the wood in search of animals where the abductors might be haunting in search of human game.

The second significant semiotic term is the ship. This is a clear reference to the instrument of voyage and transition from the original sign system, which is a reference to the intrasemiotic or intralingual system, to the interlingual environment. The results of the wandering may be situated within his presence in the deep Atlantic Ocean or through divine survival and successful arrival in the new world. The semiotic object, it is worthy of note, may not be static. It could be a reference to the ship which is the object of sail to the new world. Each semiotic object has a significant contribution to interpretation in the translation enterprise.

It is debatable that abduction is the consequence of unrestrained movement. Of course, that was the lot of anyone who embarked on movement during the era. Movements were restricted as folks kept indoor not unmindful of the looming attacks from marauders who were prospecting for slaves. It became a standard for measuring inhumanity as they easily concluded that the hawk knew how to take care of her own kids but would steal other people's kids unmindful of the pains arising from such gesture.

It may be argued that comfort is a state according to the self. It does not matter what others may be passing through. That was the warped perspective from which the issue of colonialism was viewed. The opportunity of interacting with folks in the affected environment after many decades of the onslaught provides veritable insight into the remnants of the era. Where this endeavour may not be termed history, it is para-historical negation of the dominant discourse and synonymous with what McClintock Anne (2015) considers to be "a parallel history which is now changing our understanding of our transcultural understanding."

The prime place of translation is the fact that the text may not be wholly understood by members of the younger generation from the emerging culture without the aid of translation. The folks are quite familiar with the songs and the contents may not be difficult to understand especially, at the literal level. However, not many of the folks could provide the background information that 
necessitated the composition of the song, and other related idiomatic expressions. The history and the associated orgies surrounding these may be appreciated through translation.

Gottlieb (2018) substantiated the preceding claim in the discussion of diachronic translation. According to him, "when studying translation, a striking paradox lies in the fact that translations often come closer to a meaningful representation of the original itself." The indisputable truth in Gottlieb (2018) may not be denied. The study, for instance, becomes an addition to the knowledge of folks both in the intrasemiotic and intersemiotic environments. Intrasemiotic environment refers to the originating culture of the texts in the study. Intersemiotic, on the other hand, refers to the new sign system where the translation is directed.

\section{Semiotic Objects as Validation of History}

Semiotic objects are visible signs. They dot every clime. These objects were amply deployed during the era under study. They were the cannons; the material components of the ideological thrust of the quest for control. They brought manifestation to the ideologies of the conquerors that may have been foreshadowed by the meta-narrative otherwise known as the canons. The canons are laden with meanings. What the canons, finding expression in the theories could not achieve, are easily annexed through force and despoliation of the unarmed folks in indigenous societies. The semiotic objects imply power, possession, overbearing fort of manipulation and conquest. What the canons may have outlined is brought to fruition through warfare for which these cannons (eturu) are significant. These are references to the outcome of the onslaught and the folks that were caught in the crossfire of domination in the new world and beyond.

The population of the descendants of black folks living in the western world in the twenty first century clearly attests to the magnitude of the people that were forcefully shipped to the new world and other climes during the era of slavery and slave trade. They authenticate the ballad and lend credence to the onslaught in time and space. Everywhere in Europe and the Americas has a sizeable population of black folks. These are the results of the cannons, slave 
buildings or castles that the ships conveyed to the new world for a self serving purpose such that the argument that the colonisation was necessitated by the degree of barbarity of the black folks could not be accepted as a motivating factor.

Wikipedia (2019) sources reveal the following demographic trends about the African-Americans that are resident in the former strongholds of slave owners in the United States of America and other parts of the world. The African-Americans living in the United States of America account for 13\% of the population as at August 2019 demographic computation. As at 2017, a total of 40,610, 815 representing 12.7\% of the total population of African Americans are living in the U.S. Folks from Africa are reputed to amount to the third largest racial and ethnic group in the U. S. Most of the folks are descendants of emancipated captives who were scuttled from their roots in West and Central Africa at the beginning of the $16^{\text {th }}$ century until the abolition in 1865 .

In the neighbouring Jamaica, black folks represent the majority of the people in the country representing $2,471,946$ of the population according to the population census of 2011. These folks were abducted from their ancestral roots in Fante, Igbo, Yorubá, Kongo, Fon and Ibibio whose migration began around the seventeenth century. Black British constitute 3.0\% of the population representing $0.7 \%$ of the population living in Scotland. In Wales, about 18, 276 of the people are blacks representing $0.6 \%$ of the population of people while in Northern Ireland, 3, 616 representing $0.2 \%$ of the population according to the 2011 census are blacks in the British peninsular. In Argentina, black people constitute 149,493 representing $0.37 \%$ of the population according to the 2010 census. Relics of black people may be found all over the world most of who may be descendants of emancipated slaves.

\section{Conclusion/Recommendation}

This study is preoccupied with what Gottlieb (2018) considers to be interlingual translation. It begins with the intrasemiotic interpretation of the signs and lexical items from the originating system. Through the historical and semiotic illuminations provided, the songs and wise sayings become better

\section{Mistiqiya}

International Journal of African-Egyptian Studies

Vol. 1 Issue 2 (2021) 
appreciated by readers from the intrasemiotic and intersemiotic environments. The study concludes that it is not for lack of brunt or agility to confront the situation but as the axiom in the sign system concludes: one can't be wiser than the assailant. That summed up the helplessness of the indigenous folks in their encounters with the abductors who left wailings and deaths on their trail. The nature of the war that came unannounced and many times, in the middle of the night made helplessness the order of the day. That helplessness was like the metaphor of the fish whose death may not be due to any lack of swimming skills but the inevitability of death. One may then ask rhetorically that if the orgy at the different centres and concentration camps could not be measures, what of the glaring remnants of folks in these strange lands? It may be necessary to question karma to find out if wrongs were ever redressed or that the beast called man were not the devil ravaging and spoiling for war in the global society until the modern age.

\section{References}

Abimbola, Wande. (1968). Ijinle ohun enu ifá, 1. Glasgow, UK: Aim Press.

Abimbola, Wande. (1997). Ifá will mend our broken world. Roxbury Massachusetts: Aims Books.

Abimbola, Wande. (1997). Ifá divinatory poetry. New York: Nok Publishers Limited.

Abrahams, D. R. (1975). Personal power and social restraint in the definition of folklore in Toward new perspectives in folklore. (ed.). Americo P. et al. Austin: The University of Texas Press.

Abrams M. H. (2003). et al. A glossary of literary terms. United Kingdom: Wadsworth Cengage Learning.

Andrew Milner. (1994). Contemporary cultural theory: An introduction. London: Routledge Taylor and Francis.

Ato, Quayson, Olaniyan, Tejumola et al. (2015). African literature: An anthology of criticism and theory. Oxford: Blackwell Publishing Ltd. 
Anozie, S.O. (1981). Structural models and African poetics: Towards a pragmatic theory of literature. London: Routledge \& Kegan Paul.

Arewa, O. et al. (1975). The genesis of structures in African narrative: Zande trickster tales: v. 1. New York: Conch Magazines Ltd.

Bascom, William. (1969). Ifa divination: Communication between gods and men in West Africa. London: Indiana University Press.

Bamgbose, Ayo. (1969). Yorubá folktales. Ibadan, 27, 1969.

Bauman, Richard. (2020). Performance in A companion to folklore. Google.com Books.

Ben-Amos, D. (1975). Toward a definition of folklore in context in Toward new perspectives in folklore. (ed.). Americo P, et al. Austin: the University of Texas Press.

Bucknell, Brad. (2020). Henry Louis Gates, Jr. and the theory of signifying. Google online.

Campbell, Joseph. (2019). The power of myth. New York: Doubleday Dell Publishing Group, Inc.

Dasylva, Ademola. (1994). Towards a new taxonomy of the hero in the African novel. PhD Thesis, University of Ibadan, Ibadan.

Dorson, Richard M. (1976). Folklore and fakelore: Essays toward a discipline offolk studies. Cambridge, MA: Harvard University Press.

Dundes, Alan. (1975). Folk ideas as units of worldview in Toward new perspectives in folklore._(ed.). Americo, P. et al. Austin : The University of Texas Press.

Dundes, Alan. (ed.). (1965). The study of folklore. Englewood: Prentice Hall.

Ekwueme, Laz. (2002). Composing contemporary African choral music:

Problems and prospects in Music in Africa: Facts and illusion. Ibadan: Stirling-Horden Publishers Nigeria Limited.

\section{Nistiqiya}

International Journal of African-Egyptian Studies

Vol. 1 Issue 2 (2021) 
Finnegan, Ruth. (1992). Oral poetry in nature, significance, and social context. Cambridge: Cambridge University Press.

Flaubert, Gustave. (1965). Shortcomings of Taine's theory in The modern tradition: Backgrounds of modern literature. Ellmann R., et al, (ed.). New York: Oxford University Press.

Francis Vas da Silva. (2020). Tradition without End in A companion to folklore. Google.com Books.

Gates, Henry Louis. (1989). Signifying monkey: A theory of African-American literary criticism. Oxford: Oxford University Press.

Goldstein, Diane. (2007). Health and the stigmatised vernacular. Panel chair at the annual meeting of American folklore society, Quebec, October.

Grafeldi, Juali. (2019). What is the meaning of woeful ballad?" https://www.quora.com. RetrievedSeptember.

Haley, Alex. (1976). Roots. New York: Doubleday.

Henrik Gottlieb. (2018). Semiotics and translation in The Routledge handbook of translation studies and linguistics, Kirsten Malmkjaer (ed.). New York: Routledge Taylor and Francis.

Iain, McLean et al. (2003). Oxford concise dictionary of politics. Oxford: Oxford University Press.

Jonathan, Roper. (2007). Thoms and the unachieved folk-lore of England in Folklore, Vol.118.

Machlis, Joseph. (1955). The enjoyment of music. New York: W. W. Norton \& Company Inc.

Maulana, Karenga. (1999). Odu ifá: The ethical teachings. Los Angeles: University of Sankore Press.

McClintock, Anne. (2015). The angel of progress: Pitfalls of the term postcolonialism in Ato, Quayson. Olaniyan, Tejumola et al. (ed.). African 
literature: An anthology of criticism and theory. Oxford: Blackwell Publishing Ltd.

Ogunpolu, Babatunde. (1990). Okosi festival songs in Yorubá oral tradition.

(ed.). Wande, Abimbola. Ibadan: University Press.

Okpewho, Isidore. (1981). Myth and rationality in Africa in Ibadan journal of humanistic Studies. (ed.). Ayo Banjo. Ibadan: Ibadan University Press.

Okpewho, Isidore. (1992). African oral literature: Backgrounds, character and continuity. Indiana: Indiana University Press.

Propp, Vladimir. (1928). Morphology of folktales. Torino.

Ranjan, Datta. (2017). Traditional storytelling: An effective indigenous research methodology and its implications for environmental research in Michael Walker et al. AlterNative: An international journal of indigenous peoples: Sage Journals. New Zealand: University of Auckland.

Shakespeare, William. (2019). Macbeth. Oxford: Blackwell Publishing Ltd.

Seitel, Peter. (2020). Three aspects of oral textuality in A companion to folklore. Google.com Books.

Sekoni, Ropo. (1994). Folk poetics: A sociosemiotic study of Yor̀bá trickster tales. Westport: Greenwood Press.

Soyinka, I. Ogunbusola. (2019). The cosmic beginnings: The chaos chronicals, Vol. 1.http://www.amazon.comRetrievedSeptember 2019.

Stecconi, Ubaldo. (2010). What happens if we think that translating is a wave?" Translation studies. 2: 2: 47-60.

Levi-Strauss, C. (1955). The structural of myth in Journal of American folklore, No. 270. 1955.

Taine, Hippolyte. (1965). Art as historical product in The modern tradition: Backgrounds of modern literature. (ed.). Ellmann Richard, et al. New York: Oxford University Press. 
Tejumola, Olaniyan. (2015). Postmodernity, postcoloniality and African studies in Ato, Quayson. Olaniyan, Tejumola et al. (ed.). African literature: An anthology of criticism and theory. Oxford: Blackwell Publishing Ltd.

Von Sydow, C. W. (1948). On the spread of tradition in Lauritz Bodker (ed.). Selected papers on folklore. Copenhagen.

w.w.w.wikipedia online/source/Retrieved/May/2020. 